\title{
Influence of Indole-3-Butyric Acid on Root Promotion on Vegetative Propagation of Leucophyllum frutescens under Mist Chamber of Semi-arid Tropic Region
}

\author{
A. D. Ashok* and J. Ravivarman \\ Institute of Agriculture, Tamil Nadu Agricultural University, Kumulur - 621712, Trichy, India \\ *Corresponding author
}

\section{A B S T R A C T}

\begin{tabular}{|l|}
\hline K e y w o r d s \\
$\begin{array}{l}\text { Leucophyllum } \\
\text { frutescens, IBA, } \\
\text { rooting hormone, } \\
\text { quick dip method, } \\
\text { hardwood }\end{array}$ \\
\hline Article Info \\
\hline $\begin{array}{l}\text { Accepted: } \\
\text { 22 June } 2020 \\
\text { Available Online: } \\
\text { 10 July } 2020\end{array}$ \\
\hline
\end{tabular}

\begin{abstract}
The experiment was conducted at Institute of Agriculture, Tamil Nadu Agricultural University, Kumulur, Tiruchirappalli district of Tamilnadu, India. The experiment was laid out in Completely Randomized Block Design (FCRD) with 2 replications, including seven treatments of various concentration of IBA solutions viz., 500 ppm, 1000 ppm, 1500 ppm, 2000 ppm, 2500 ppm, 3000 ppm and control (without any treatment). Hardwood cuttings of Leucophyllum frutescens were treated in quick dip method for 30 seconds and planted under mist chamber for rooting. Minimum days of sprouting ( 9.25 days), higher rooting percentage $(79.15 \%)$, maximum root length $(15.70 \mathrm{~cm})$ and maximum shoot length $(8.75$ $\mathrm{cm}$ ) were recorded in $3000 \mathrm{ppm}$ concentration of IBA. We conclude from this experiment that quick dipping for 30 seconds with $3000 \mathrm{ppm}$ of IBA will promote earlier rooting, maximum rooting percentage, improved root and shoot growth in propagation through rooting of Leucophyllum frutescens hardwood cuttings under mist chamber conditions of semi-arid tropical region.
\end{abstract}

\section{Introduction}

Leucophyllum frutescens belonging to family Scrophulariaceae is a medium-sized shrub with compact growth and delicate silvery to gray-green leaves. It is native to Texas and Mexico but now widely cultivated in Florida and South East Asia (Hussain et al., 2016). It is a good ornamental plant and commonly used for edge and flowering shrubbery in warmer and drier areas. It is a popular plant in xeriscape gardens. Normally, this bush is vegetatively propagated through stem cuttings. Among the vegetative propagation methods, stem cutting is the easiest and cost effective method of multiplication mainly for ornamental shrubs.

The rooting ability and success percentage of cuttings depends on many factors such as variety, season, location, age of the mother plant, part of the plants used, nutrient status of the cutting, climatic conditions, aftercare etc. As well, plant growth regulators also play an important role in formation of roots and shoot growth in cuttings. Root commencement with the exogenous application of plant growth regulators occupies a significant role in the 
field of plant propagation (Mukherjee et al., 1976).

Cuttings treated with plant growth regulators at optimum concentration will induce more rooting compared to untreated one, sometimes in the species which will not root easily under normal conditions. Action of growth regulator is based on the concentration of hormone applied which differs with type of species and cuttings etc. Auxin is well known to improve rooting of different types of cuttings. The development of root primordium cells depends on the endogenous Auxins in the cutting and synergic composite such as a diphenol. These substances lead to the synthesis of ribonucleic acid (RNA), which act upon root primordium initiation (Hartmann et al., 2002). Exogenous Auxins are commonly used to improve rooting efficiency and quality of stem-cuttings. Treatment of cuttings with rooting hormones has been reported to improve rooting in many woody and semi woody species. Hence, the present study has been taken up to understand the method of propagation through stem cutting of Leucophyllum frutescens along with the treatment of plant growth regulator at semi-arid tropical zone of Tamilnadu.

\section{Materials and Methods}

The experiment was conducted at Institute of Agriculture, Tamil Nadu Agricultural University, Kumulur, Tiruchirappalli district of Tamilnadu, India. The experiment was laid out in Completely Randomized Block Design (FCRD) with 2 replications, including seven treatments of various concentration of Indole3-Butyric Acid (IBA) solutions viz., 500 ppm, 1000 ppm, 1500 ppm, 2000 ppm, 2500 ppm, $3000 \mathrm{ppm}$ and control (without any treatment). Hardwood stem cuttings of pencil thickness were collected from healthy mother plants available in the institute. Hardwood cuttings of $20 \mathrm{~cm}$ length with minimum 3-4 nodes without leaves were taken. A slant cut was given at the basal end and a transverse cut at the top of each cutting. The basal end $(2.5-3.0 \mathrm{~cm})$ of the cuttings was dipped for 30 seconds with IBA solutions. Then, the treated cuttings were planted vertically in sterilized inert sand media under mist chamber condition to promote rooting. All cuttings were maintained under mist chamber and watered regularly. Relative humidity in the mist chamber was maintained at $\geq 85 \%$ and temperature at $30 \pm 2^{0} \mathrm{C}$. Further observations were recorded at 45 days after planting (DAP) on various shoot and root parameters such as days taken for sprouting, rooting percentage (\%), number of buds sprouted, root length $(\mathrm{cm})$, shoot length $(\mathrm{cm})$ and number of leaves formed on cuttings. The inference was drawn after comparing the calculated $\mathrm{F}$ values with the tabulated $\mathrm{F}$ values at $5 \%(\mathrm{P}=0.05)$ level of significance. The estimates of mean, variance and standard error were done as per Panse and Sukhatme (1967).

\section{Results and Discussion}

In this study, the results shows (table 1) significance on the parameters such as days for sprouting, rooting percentage root length and shoot length. But it not showed any significant effect on number of buds per cutting and number of leaves per cutting, though it shows variations. Cuttings of $L$. frutescens had minimum days of sprouting (9.25 days) at the IBA concentration of 3000 $\mathrm{ppm}$. All the treatment are significant from control (without IBA) in days for sprouting but on par with each other. Rooting percentage of the cuttings also shows higher in $3000 \mathrm{ppm}$ concentration (79.15\%). But it is on par with other concentrations such as $2500 \mathrm{ppm}$ (75.25\%), $2000 \mathrm{ppm}$ (70.60\%), $1500(65.60 \%)$ and 1000 (58.35\%). This observation clearly denotes that, IBA treatment encourages quick sprouting and 
maximum rooting percentage of cuttings irrespective of concentrations. Also it is clear that effect of root promotion through quick dipping of rooting hormone is directly proportionate to the concentration of rooting hormone treated. Our findings are in line with experimental reports of Hussain and Urbi (2016) on adventitious rooting in shoot cuttings of Andrographis paniculata. They stated that higher concentration of NAA resulted in an increased number of adventitious rooting per cutting. Similar reports were given by Raji and Osman (2012) and Dash et al., (2011) as that the higher dosages of auxins induced increased number of roots within a short time.

Table.1 Effect of IBA on rooting of Leucophyllum frutescens

\begin{tabular}{|l|c|c|c|c|c|c|}
\hline Concentrations & $\begin{array}{c}\text { Days for } \\
\text { sprouting }\end{array}$ & $\begin{array}{c}\text { Rooting } \\
\text { percentage } \\
\mathbf{( \% )}\end{array}$ & $\begin{array}{c}\text { Number of buds } \\
\text { per cutting }\end{array}$ & $\begin{array}{c}\text { Root } \\
\text { length } \\
\text { (cm) }\end{array}$ & $\begin{array}{c}\text { Shoot } \\
\text { length } \\
\text { (cm) }\end{array}$ & $\begin{array}{c}\text { No. of } \\
\text { leaves per } \\
\text { cutting }\end{array}$ \\
\hline $\mathbf{5 0 0} \mathbf{~ p p m}$ & 12.25 & 55.65 & 3.35 & 9.10 & 5.97 & 12.42 \\
\hline $\mathbf{1 0 0 0} \mathbf{~ p p m}$ & 12.15 & 58.35 & 3.45 & 10.65 & 6.55 & 12.96 \\
\hline $\mathbf{1 5 0 0} \mathbf{~ p p m}$ & 11.50 & 65.60 & 3.70 & 12.57 & 7.10 & 14.04 \\
\hline $\mathbf{2 0 0 0} \mathbf{~ p p m}$ & 10.35 & 70.60 & 3.90 & 12.55 & 7.25 & 14.04 \\
\hline $\mathbf{2 5 0 0} \mathbf{~ p p m}$ & 9.75 & 75.25 & 4.10 & 14.85 & 8.25 & 15.28 \\
\hline $\mathbf{3 0 0 0} \mathbf{~ p p m}$ & 9.25 & 79.15 & 4.45 & 15.70 & 8.75 & 15.66 \\
\hline Control & 16.35 & 30.30 & 3.10 & 7.60 & 4.50 & 11.34 \\
\hline Mean & 11.66 & 62.13 & 3.72 & 11.86 & 6.91 & 13.68 \\
\hline SE.d & 1.68 & 9.05 & 0.53 & 1.72 & 0.99 & 1.94 \\
\hline CD & 3.60 & 19.40 & $1.14(\mathrm{NS})$ & 3.69 & 2.13 & 4.17 (NS) \\
\hline
\end{tabular}

Maximum root length $(15.70 \mathrm{~cm})$ was recorded in $3000 \mathrm{ppm}$ IBA concentration, followed by $2500 \mathrm{ppm}(14.85 \mathrm{~cm}), 2000 \mathrm{ppm}$ $(12.55 \mathrm{~cm})$ and $1500 \mathrm{ppm}(12.57 \mathrm{~cm})$ which are on par with each other. Shenoy, 1992 in Rosa damascena reported that the increase in root length over control may be due to the enhanced hydrolysis of carbohydrates, metabolites accumulation and cell division induced by Auxin. These results were in line with the findings of Patil et al., $1998^{[8]}$ in Jasminum sambac (Jasmine), Singh et al., 2010 in Bougainvillea glabra (bougainvillea), Grewal et al., 2005 in Dendranthema grandiflora cv. Snowball, Singh et al., 2013 in Cestrum nocturnum (night jasmine) and Sharma, 2014 in Tagetes erecta (marigold). The shoot length of the sprouts has its highest growth in $3000 \mathrm{ppm}$ treatment $(8.75 \mathrm{~cm})$, followed by $2500 \mathrm{ppm}(8.25 \mathrm{~cm}), 2000 \mathrm{ppm}$ $(7.25 \mathrm{~cm})$ and $1500 \mathrm{ppm}(7.10 \mathrm{~cm})$ which are on par with each other. The increased shoot length of hardwood cuttings may be due to the active root growth and more number of roots per cutting, which in turn increased the uptake of water and nutrients. In IBA treated cuttings, Auxin enhanced the cell division, cell elongation and production of protein synthesis which might have resulted in enhanced healthy vegetative growth. Similar findings were observed by Girisha et al., 2012 in Bellis perennis (daisy) and Singh and Negi, 2014 in Tecoma stans (yellow bells).

On observing number of buds sprouted per cutting, number of leaves per cutting there is no significant difference was observed. By this experiment, pertaining to the effect of IBA on rooting of Leucophyllum frutescens hardwood stem cuttings, we can observe that the rooting hormone IBA have the capacity to promote more rooting which results in quick 
sprouting and maximum rooting percentage; also stimulate the growth of root. The effect of rooting hormone on increasing number of sprouts and leaf growth has no significant differences among the various concentrations and control. Since we are using sand, an inert rooting media, we easily identified the effect of IBA on root promotion in Leucophyllum.

We conclude from this experiment that quick dipping for 30 seconds with 3000 ppm of IBA will promote earlier rooting, maximum rooting percentage and improved root and shoot growth in propagation through rooting of Leucophyllum frutescens hardwood cuttings under mist chamber conditions of semi-arid tropical region. Further studies may be promoted by increasing the concentration of rooting hormone to standardise the maximum dosage of IBA promotes maximum rooting.

\section{References}

Bailey L.H and Bailey E.Z. 1976. Hortus third: A concise dictionary of plants cultivated in the United States and Canada. Macmillan Publishing Co., New York.

Dash G.K., S.K. Senapati, G.R. Rout. 2011. Effect of auxins on adventitious root development from nodal cuttings of Saraca asoka (Roxb.) de Wilde and associated biochemical changes. Journal of Horticulture and Forestry. 3(10): 320-326.

Girisha R, A.M. Shirol, B.S. Reddy, V.K. Patil and Krishnamurthy G.H. 2012. Growth, quality and yield characteristics of daisy (Aster amellus L.) cultivar Dwarf Pink as influenced by different plant growth regulators. Karnataka Journal of Agricultural Science. 25(1):163-165.

Grewal H.S., R Kumar and Chauhan R. 2005. Effect of IBA and NAA on rooting in chrysanthemum

(Dendranthema grandiflora Tzevlev) terminal cuttings. Journal of Ornamental Horticulture. 8(3):230-232.

Hartmann H.T., D.E Kester, F.T Davis and Geneve R.L. 2002. Plant propagation: principles and practices, New Jersey: Prentice Hall.

Hossain M.S. and Urbi Z. 2016. Effect of naphthalene acetic acid on the adventitious rooting in shoot cuttings of Andrographis paniculata (Burm.f.) Wall. ex Nees: an important therapeutical herb. International Journal of Agronomy. Article ID: 1617543.

Hussain I, M Bhutta, N Amin, M Khattak, A Shah, S Hussain and Zeb N. 2016. Growing Conditions and Planting Dates Affect the Vegetative Growth of Silvery (Leucophyllum frutescens). Sarhad Journal of Agriculture. 32. 104111.

Mukherjee T.P., T Roy and Bose T.K. 1976. Standardization of propagation from cuttings under mist, II. Effect of rooting media on root formation in cutting of ornamental plants, Journal Punjab Hort. 16:153-156.

Panse V.G. and Sukhatme PV. 1978. Statistical methods for agricultural workers. 3rd Ed. New Delhi: Indian Council of Agricultural Research.

Patil B and Kanamadi V.C. 1998. Effect of growth regulators on the rooting of hardwood cuttings in jasmine. Advances in Forestry Research in India. 19:225-229.

Raji A.A and Osman M. 2012. Effects of stem cutting types, position and hormonal factors on rooting in Stevia rebaudiana Bertoni. Journal of Agricultural Science. 4(1): 49-57.

Sharma R. 2014. Study on the effect of Auxins on rooting, growth and flowering of African marigold (Tagetes erecta L.) propagated through stem 
cuttings, M. Sc., (Hort.) thesis. Singh K.K, V Rawat, J.M.S. Rawat, Y.K. I.G.K.V., Raipur.

Shenoy R. 1992. Influence of planting material and growth regulators on the rooting of stem cuttings in Rosa damascena Mill, M. Sc., (Hort.) Thesis submitted to the University of Agricultural Sciences, Bangalore.

Singh K.K and Negi B. 2014. Effect of various concentrations of IBA and length of cutting on the rooting in stem cutting of Tecoma stans L. under mist chamber, International journal of Current Research. 6(12):10946-10949. Tomar and Kumar P. 2013. Effect of IBA and NAA concentrations on rooting in stem cuttings of Night queen (Cestrum nocturnum L) under subtropical valley conditions. Hort. Flora Research Spectrum. 2(1):81-83.

Singh N, B.P Singh and Singh H.K. 2010. Effect of different concentrations of Indole Butyric Acid (IBA) on rooting potential and root growth of Bougainvillea stem cuttings. Journal of Ornamental Horticulture. 13(1):41-44.

\section{How to cite this article:}

Ashok, A. D. and Ravivarman, J. 2020. Influence of Indole-3-Butyric Acid on Root Promotion on Vegetative Propagation of Leucophyllum frutescens under Mist Chamber of Semi-arid Tropic Region. Int.J.Curr.Microbiol.App.Sci. 9(07): 3052-3056. doi: https://doi.org/10.20546/ijcmas.2020.907.360 